\title{
Effervescent Powder Dosage Form
}

National Cancer Institute

\section{Source}

National Cancer Institute. Effervescent Powder Dosage Form. NCI Thesaurus. Code C64884.

A powder composed of active and/or inert ing redient(s), and a mixture of acids and sodium bicarbonate, which release carbon dioxide when dissolved in water. 